\title{
Hydraulic properties from pumping tests data of aquifers in Azare area, North Eastern Nigeria.
}

\author{
AKAHA .C. TSE; PROMISE A. AMADI \\ Department of Geology, University of Port Harcourt, Nigeria \\ akacelts@yahoocom.08055364149
}

\begin{abstract}
Pumping test data from twelve boreholes in Azare area were analysed to determine the hydraulic properties of the aquifers, and the availability of water to meet the conjugate demands of the increasing population. The values of the aquifer constants obtained from the Cooper-Jacob's non-equilibrium graphical method were generally low. Yield, Q, values range from 2.24 to $17.46 \mathrm{~m}^{3} / \mathrm{hr}\left(6.22 \times 10^{-4}\right.$ to $\left.4.85 \times 10^{-3} \mathrm{~m} / \mathrm{sec}\right)$, while Transmissivity, T, fell between $7.39 \times 10^{-6}$ and $3.55 \times 10^{-4} \mathrm{~m}^{2} / \mathrm{sec}$ and hydraulic conductivity, $\mathrm{K}$, from $5.62 \times 10^{-7}$ to $42.54 \times 10^{-5} \mathrm{~m} / \mathrm{sec}$. The average specific capacity, Cs, value is $2.10 \times 10^{-4} \mathrm{~m}^{3} / \mathrm{sec} / \mathrm{m}$. The total yield is $98.67 \mathrm{~m}^{3} / \mathrm{hr}$ or $2368.08 \mathrm{~m}^{3} /$ day, and drawdowns in excess of $20 \mathrm{~m}$ were recorded. These values indicate that the hydraulic characteristics of the aquifers are poor. The implication is that the available boreholes cannot provide sufficient water for domestic and agricultural needs of the area. The Azare area therefore will continue to face severe water supply problems with increasing populations unless more wells are drilled, and supplemented by water impoundment using dams. @ JASEM
\end{abstract}

In Azare area of North Eastern Nigeria, groundwater is the main source of potable water. This is due to its location in the sub Saharan region of the southern Sahel where rainfall is scanty, no substantial surface water bodies exists and evapotranspiration is high. Basement rocks contribute to underground water sources when they are weathered or fractured, and the overlying sandy Kerri Kerri Formation constitute a major regional aquifer but the sands are frequently dry. Increasing local population in the area (from 69,035 in 1991 to 110,452 in 2007), coupled with semi- desert conditions and the agrarian activities requiring irrigation implies increasing demand for water for domestic and agricultural uses. The aim of this paper is to investigate the hydraulic characteristics of aquifers from available borehole data in the area, to ensure proper documentation of

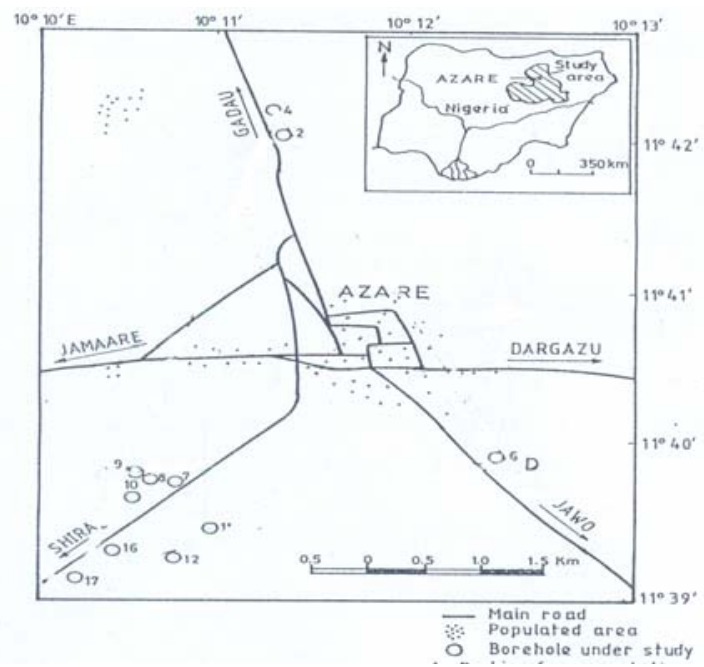

Fig. 1: Layout of Azare Town and the location of study boreholes. quantifiable results for effective management of current resources and planning of future ones.

The study area is located between latitudes $11^{\circ} 39^{\prime}$ and $11^{\circ} 43^{\prime} \mathrm{N}$ and longitudes $10^{\circ} 10^{\prime}$ and $10^{\circ} 12^{\prime} \mathrm{E}$ in the northern part of Bauchi state of Nigeria (Fig 1). The Azare area lies within the Sahel Savannah and has a semi-tropical climate. There are two distinct seasons, the wet and the dry. The wet season begins in April and ends in October. Even during this season, not much rain is recorded compared with the southern parts of Nigeria. The dry season lasts between November and March with little or no rain. Generally, the mean annual total rainfall is $763 \mathrm{~mm}$, with peaks between July and September, as compared with about $4000 \mathrm{~mm}$ in the south of Nigeria. Temperatures are generally high during April and May but low during the cold harmattan between November and February.

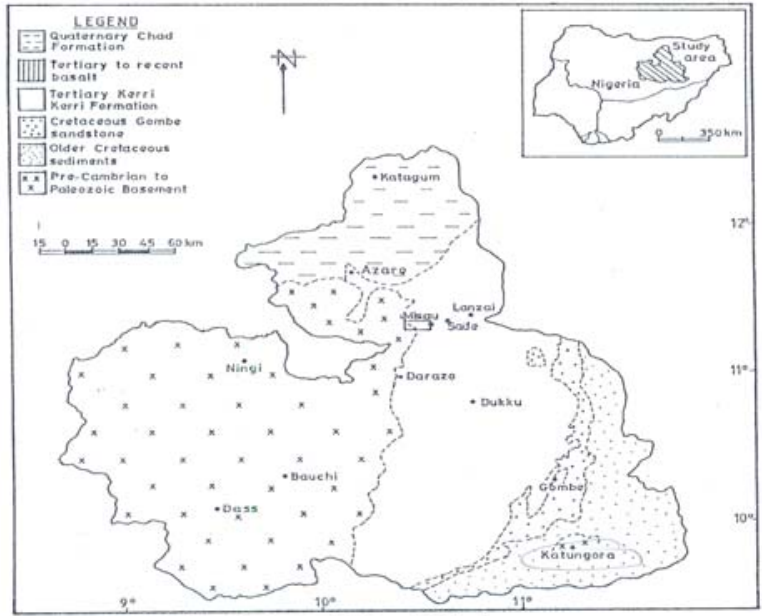

Fig. 2: Position of Azare in relation to the regional geology of surrounding areas. 


\section{Geologic setting}

Previous geological and hydro geological studies of the Azare area are few. However, Thompson (1958), Carter et al (1963) and Du Preez and Barber (1965), Edok-Eter (1976), Water Surveys (1978), Dike (1990), Dike and Dan Hassan (1990) and Umaru and Schoeneich (1992) have described aspects of the geology of the Upper Benue Trough, and the hydrogeology of parts of Bauchi State where the study area is located but no specific work on aquifer performance in Azare area has been encountered in literature. The general geology of the Upper Benue Trough is summarized in Fig.2. The stratigraphic succession the upper Benue Trough consists of folded Cretaceous sediments called the Bima Sandstones unconformbly overlying the Precambrian to Paleozoic Basement. This is succeeded by the Cretaceous Gombe sandstones which passes upwards into the Tertiary sands of the Kerri Kerri .Formation. The sequence is terminated by the Quaternary Chad Formation. In Azare area, the local geology consists of sediments of the Tertiary Kerri-Kerri Formation, unconformably overlying the Precambrian to Early Paleozoic Basement Complex rocks. The Kerri-Kerri Formation is a continental sequence of Paleocene age (Adegoke et al 1986) deposited under alluvial, fluvial and marginal lacustrine conditions (Carter et a. 1963, Du Preez and Barber, (1965). Lithologically, the Kerri-Kerri Formation consists of fine, medium to coarse sandstone and sand, siltstone and silt, claystone and clay as well as ironstone. The sands are usually silty, clayey, occasionally micaceous and even pebbly in some localities. The top of the formation is intensely lateritised. The Kerri-Kerri Formation is said to represent molasse deposits following the Late Cretaceous folding phase that affected the Upper Benue Trough (Benkhelil, 1989). It is known to be about $320 \mathrm{~m}$ metres thick, (Dike 1990), but in the study area the maximum proven thickness is only about 50 metres. The proven thickness of the KerriKerri may indicate that the study area is near the edge of the formation. The Basement Complex rocks consist mainly of granites and gneisses which exhibit various degrees of weathering and minor deformations. The weathered granite and gneiss overburden contain clays, mostly kaolinite and small proportions of sand comprising quartz and weathered feldspars derived from the basement rocks. These rocks are fractured only in places. In the Azare area, the basement rocks are encountered at shallow depths uncomfortably underlying the Kerri-Kerri Formation (Dike and DanHassan (1990). Within the study area, two aquifer units are recognized in the Kerri -Kerri and the underlying weathered and fractured basement rocks. Thus all boreholes terminate in the basement rocks.

\section{MATERIALS AND METHODS}

Lithologic logs and pumping test results for twelve representative boreholes were obtained from the Bauchi State Water Board for this study. The boreholes were chosen on account of availability of the relevant data needed, including lithologic logs and pumping test results. Supplementary geological and hydrogeological information were obtained from available maps and records of hand dug wells. The logs enabled the establishment of the subsurface stratification, casing and screen positions, static water levels and aquifer textural properties while the aquifer pumping test data for each borehole comprised 3 to 4 stage step-drawdown tests, single stage and recovery measurements. These were used to determine aquifer hydraulic properties such as transmissivity (T), hydraulic conductivity $(\mathrm{K})$ and specific capacity (Cs). Pumping test data analysis was based on the Cooper-Jacob's (1946) nonequilibrium graphical method. This method has been found suitable where the abstraction well itself serves as the observation well, as is the case in the present study. By this method, the transmissivity (T) is given by:

$$
\mathrm{T}=\frac{2.303 \mathrm{Q}}{4 \Pi \Delta \mathrm{S}} \cdots . .(1)
$$

Where $Q=$ discharge or yield $\left(\mathrm{m}^{3} / \mathrm{sec}\right)$.

$\Delta \mathrm{S}=$ change in drawdown over one log cycle.

This formula is useful because some of the boreholes are confined while others are semi-confined. The average drawdown for the twelve boreholes is about $20.41 \mathrm{~m}$. The hydraulic conductivity (K) was calculated from

$\begin{array}{rlll}\mathrm{K} & =\frac{\mathrm{T}}{\mathrm{b}} \quad \ldots .(2) \\ \text { Where } \mathrm{T} & = & \text { as in (1) above } \\ \mathrm{B} & =\text { aquifer }\end{array}$
(equivalent to the total screen length).

The specific capacity (Cs), a measure of well productivity, was computed from:

$$
\begin{gathered}
\mathrm{Cs}=\frac{\mathrm{Q}}{\mathrm{S}} \ldots(3) \\
\text { Where } \mathrm{Q}=\text { as in }(1) \text { above } \\
\mathrm{S}=\text { maximum drawdown }
\end{gathered}
$$

Details of the Cooper-Jacob's method of determining aquifer hydraulic characteristics are given in standard groundwater hydrogeology and hydrology text books e.g. Todd (1980).

\section{RESULTS AND DISCUSSIONS}

The lithologic logs were carefully studied to delineate the water-bearing sections of the subsurface soil sequence (Fig.3). The hydrostratigraphic units in the study area are the sands and clayey and pebbly sands of the Kerri -Kerri Formation as well as the weathered top of the basement rocks. These 
constitute the two distinct aquifer units of the area. The overburden of the basement areas are characteristically clayey and pebbly, with the clay forming the matrix. The Kerri Kerri sands are fine, medium to coarse-grained with a preponderance of argillaceous matrix. The sands are poorly sorted. The presence of fines in the aquifers reduces porosity and permeability and consequently the yield potential of the aquifers.

As shown by the lithologs, the aquifers occur at depths of between 27 and $80 \mathrm{~m}$ under confined and semi-confined conditions. Borehole properties in terms of depth, screen intervals (assumed aquifer thickness), static and dynamic water levels, drawdown and yield together with the aquifer constants $\mathrm{T}, \mathrm{K}$ and $\mathrm{Cs}$ obtained from the CooperJacob methods are presented in Table 1 while $\mathrm{T}$ and $\mathrm{K}$ from the step-drawdown and recovery stage pumping test data are presented in Table 2. Yield or discharge $(\mathrm{Q})$ values range from $6.22 \times 10^{-4} \mathrm{~m}^{3} / \mathrm{sec}$. to 4. $85 \times 10^{-3} \mathrm{~m} / \mathrm{sec}$. The mean discharge value for the twelve boreholes is $2.28 \times 10^{-3} \mathrm{~m}^{3} / \mathrm{sec}$ (i.e. $8.22 \mathrm{~m}^{3} / \mathrm{h}$ ). As an aquifer material, the weathered basement is characterized by low yields, while the sands of the Kerri- Kerri formation give comparatively higher yields. In order to derive aquifer constants, curves of drawdown against time were constructed using the pumping test results. Typical curves are shown in Fig. 4. In general, results from the recovery method seem more reliable since the recovery data represent in-situ aquifer conditions, and they are free from the effects of pumping and interference (mainly human errors). From Table 1, transmissivity values range from $7.30 \times 10-{ }^{6} \mathrm{~m}^{2} / \mathrm{sec}$ to $3.55 \times 10^{-4} / \mathrm{sec}$ with an average of $5.35 \times 10^{-5} \mathrm{~m}^{2} / \mathrm{sec}$. These values show proportional variations with yields. The mean transmissivity value of $5.53 \times 10^{-5} \mathrm{~m}^{2} / \mathrm{sec}$ is low and is indicative of the poor permeability in the study area. The low $\mathrm{T}$ values also imply that it will take a considerable time for the aquifers to replace water into wells removed during pumping. Hydraulic conductivity values range from $5.62 \times 10^{-7} \mathrm{~m} / \mathrm{sec}$ to $2.55 \times 10^{-5} \mathrm{~m} / \mathrm{sec}$ with a mean value of $3.85 \times 10^{-}$ ${ }^{6} \mathrm{~m} / \mathrm{sec}$. The specific capacity values range from 9.87 $\mathrm{x} 10^{-6} \mathrm{~m}^{3} / \mathrm{sec} \mathrm{m}$ to $5.47 \times 10^{-4} \mathrm{~m}^{3} / \mathrm{sec} / \mathrm{m}$ with a mean of $2.1 \times 10^{-4} \mathrm{~m}^{3} / \mathrm{sec} / \mathrm{m}$. The aquifers may thus be classified on the basis of yield as poor $\left(6 \mathrm{~m}^{3} / \mathrm{h}\right)$ to moderate $\left(6-15 \mathrm{~m}^{3} / \mathrm{h}\right)$, according to the classification scheme of Dike (1990). However, a relatively higher yield of $17.46 \mathrm{~m}^{3} / \mathrm{h}$, classified as good yield, is obtained from borehole No.16. The generally low yield is due to the impact of the lithology which is characterized by clay lenses and matrix that occur within the materials of the two aquifer units. The sum of the yield from the twelve boreholes is $98.67 \mathrm{~m} 3 / \mathrm{hr}$. This gives a total yield of 2368080 litres per day. When distributed over the 2007 projected population of approximately 110500 , this will give approximately 21 litres of water per day per head. This is grossly inadequate for even basic domestic uses including shower, laundry and others. Dike (1990) in a study of the water supply in Misau Town, obtained total yield of 4,800,000 litres per day from all boreholes tapping the same aquifers which was calculated to support a population of 50,000 with an average of 96litres per day per head. He classified this result as poor aquifer yield. Misau lies about $50 \mathrm{~km}$ south east of Azare town and has similar geology and structure.

Drawdown of over between 7 and $20 \mathrm{~m}$ were recorded in most boreholes and this gives an indication of the relative inefficiency of the aquifer materials as hydraulic structures. Typical variation of borehole yield with drawdown in the area are shown in Fig.5. According to Driscoll (1986), an aquifer with a T value of less than $12.4 \mathrm{~m}^{2} /$ day $\left(0.5 \mathrm{~m}^{2} / \mathrm{h}\right.$ or $1.44 \times 10^{-}$ ${ }^{4} \mathrm{~m}^{2} / \mathrm{sec}$ ) can supply enough water only for domestic purposes, but that values ten times or more can supply adequate water for industrial, domestic and irrigation uses. Although this would appear to be water requirements for Western countries where conjugate demand and use of water is very high, this may equally apply to the Azare area given the low annual total rainfall, the long dry season periods, increasing population and the agrarian nature of its people who need much water for irrigation of crops. Thus, the twelve boreholes under study can supply water adequate for only domestic use.

The mean hydraulic conductivity value of $3.85 \times 10^{-}$ ${ }^{6} \mathrm{~m} / \mathrm{sec}$ is moderate according to classification by Todd (1980) and is typical of clayey sands (Freeze and Cherry, 1979). Since groundwater is the main source of supply in the area, and given that the boreholes available are incapable of yielding large water quantities, it implies that more boreholes supplemented by hand dug wells will be required to augment the shortfalls since increasing population will mean more water demand. Alternatively, water impoundment by earth dams will also increase the quantity of water available for supply. In addition, an efficient water management policy is imperative for sustainable water supply planning in this area of poor aquifer yields. 

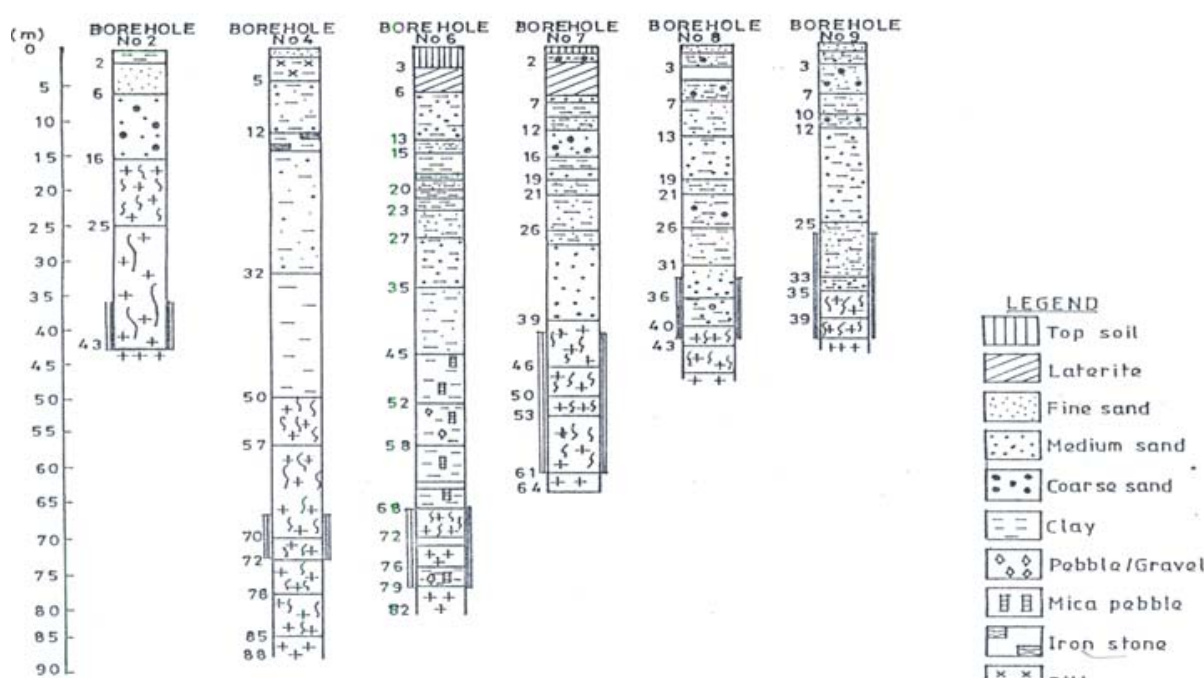

$\because \because$ Coar se sand

$E$ Ectay

$\therefore:$ Pobblalgravel

目目 Mica pebble

EDiron stone

$\left[\begin{array}{cc}x \\ x \\ x\end{array} \times x\right]$ silt
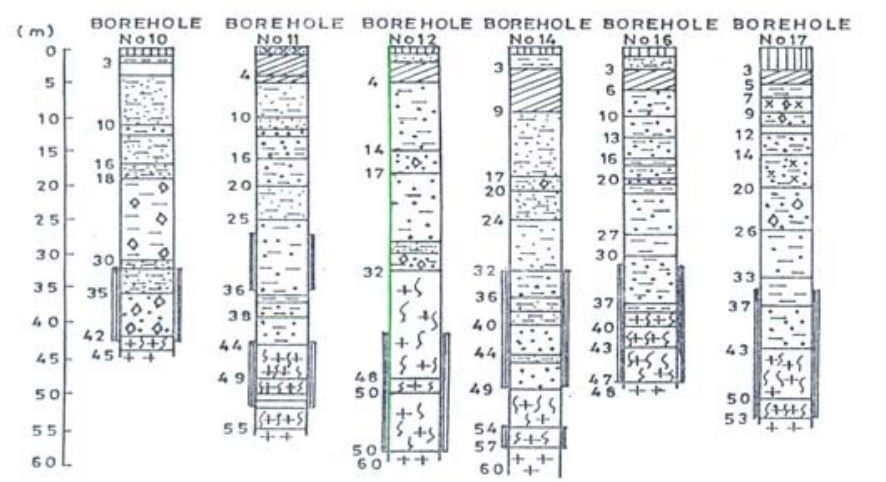

Fit Weathered

${ }^{+}+{ }^{+}$Frash granito

III II Screan

Fig. 3: Lithologic logs of the study boreholes.
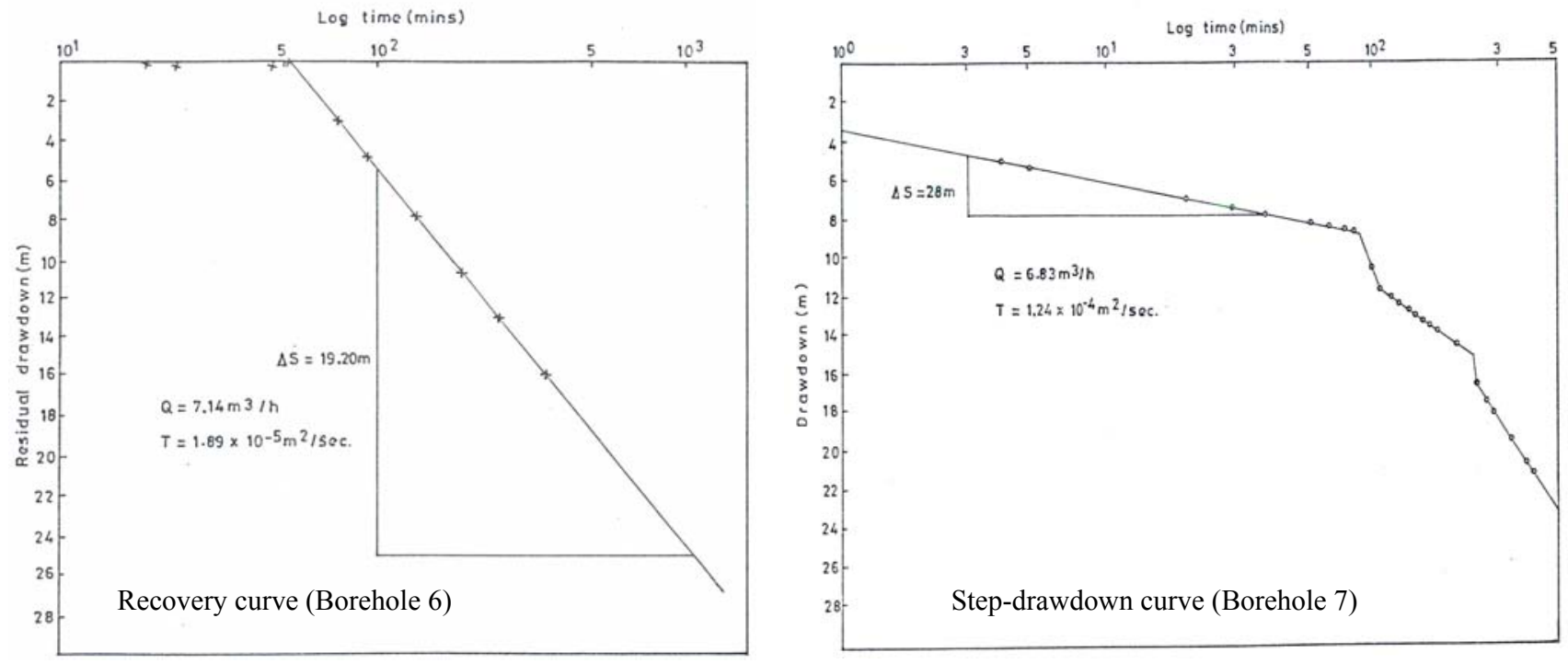

Fig. 4: Typical pumping test curves. 

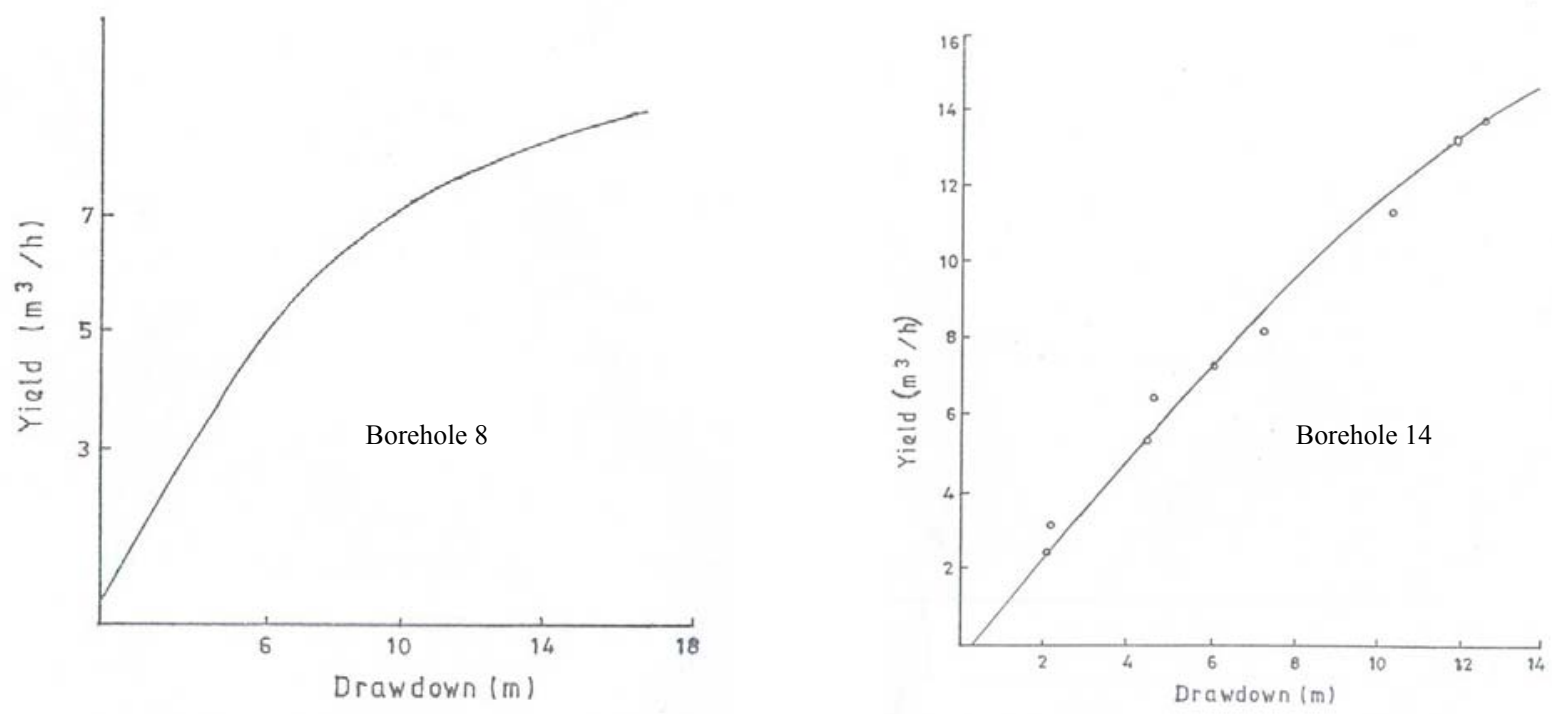

Fig. 5: Variation of drawdown with borehole yield.

Table 1: Summary of Aquifer properties in Azare area

\begin{tabular}{|c|c|c|c|c|c|c|c|c|c|c|c|}
\hline $\begin{array}{l}\text { Borehole } \\
\text { Number }\end{array}$ & $\begin{array}{l}\text { Total } \\
\text { Depth } \\
\text { (m) }\end{array}$ & Aquifer & $\begin{array}{l}\text { Screen interval } \\
(\mathrm{m})\end{array}$ & $\begin{array}{l}\text { Aquifer } \\
\text { thickness } \\
\text { (m) }\end{array}$ & $\begin{array}{l}\text { Static } \\
\text { water } \\
\text { level (m) }\end{array}$ & $\begin{array}{l}\text { Yield } \\
\left(\mathrm{m}^{3} / \mathrm{hr}\right)\end{array}$ & $\begin{array}{l}\text { Draw } \\
\text { down } \\
(\mathrm{m})\end{array}$ & $\begin{array}{l}\text { Dynamic } \\
\text { water level } \\
\text { (m) }\end{array}$ & $\begin{array}{l}\text { Transmis- } \\
\text { sivity } \\
\left(\mathrm{m}^{2} / \mathrm{sec}\right)\end{array}$ & $\begin{array}{l}\text { Hydraulic } \\
\text { conductivit } \\
\mathrm{y}(\mathrm{m} / \mathrm{sec})\end{array}$ & $\begin{array}{l}\text { Specific } \\
\text { capacity } \\
\left(\mathrm{m}^{2} / \mathrm{sec} / \mathrm{m}\right)\end{array}$ \\
\hline Azare 2 & 46 & Basement & $36-42$ & 6 & 16.48 & 4.32 & 11 & 28 & $2.15 \times 10^{-3}$ & $3.58 \times 10^{-6}$ & $1.09 \times 10^{-4}$ \\
\hline Azare 4 & 88 & Basement & $67-76$ & 9 & 21 & 3.72 & 32 & 58 & $1.45 \times 10^{-5}$ & $1.62 \times 10^{-6}$ & $3.20 \times 10^{-5}$ \\
\hline Azare 6 & 80 & Basement & $66-79$ & 13 & 28 & 2.24 & 63 & 54 & $7.30 \times 10^{-6}$ & $5.62 \times 10^{-7}$ & $9.87 \times 10^{-6}$ \\
\hline Azare 7 & 64 & Basement & $41-61$ & 30 & 11 & 8.44 & 15 & 21 & $6.31 \times 10^{-5}$ & $3.16 \times 10^{-6}$ & $1.56 \times 10^{-4}$ \\
\hline Azare 8 & 49 & KK \& B & $33-47$ & 14 & 9 & 7.73 & 7 & 16 & $1.50 \times 10^{-5}$ & $1.07 \times 10^{-6}$ & $3.07 \times 10^{-4}$ \\
\hline Azare 9 & 43 & KK \& B & $27-41$ & 14 & 8 & 13.80 & 7 & 9 & $5.39 \times 10^{-5}$ & $3.85 \times 10^{-6}$ & $5.47 \times 10^{-4}$ \\
\hline Azare 10 & 42 & KK & $30-42$ & 12 & 9 & 7.14 & 5 & 15 & $1.89 \times 10^{-5}$ & $1.58 \times 10^{-6}$ & $3.96 \times 10^{-4}$ \\
\hline Azare 11 & 54 & $\begin{array}{l}\text { Kerri Kerri } \\
\text { Basement }\end{array}$ & $\begin{array}{l}27-35 \\
42-52\end{array}$ & 18 & 14 & 7.48 & 35 & 50 & $2.86 \times 10^{-5}$ & $1.59 \times 10^{-6}$ & $5.94 \times 10^{-5}$ \\
\hline Azare 12 & 60 & Basement & $32-48$ & 17 & 13 & 7.14 & 23 & 32 & $2.79 \times 10^{-5}$ & $1.61 \times 10^{-6}$ & $8.60 \times 10^{-5}$ \\
\hline Azare 14 & 60 & $\begin{array}{l}\text { Kerri Kerri } \\
\text { Basement }\end{array}$ & $\begin{array}{l}32-49 \\
55-59\end{array}$ & 20 & 16 & 10.47 & 18 & 35 & $4.09 \times 10^{-5}$ & $2.06 \times 10^{-6}$ & $1.61 \times 10^{-4}$ \\
\hline Azare 16 & 48 & KK \& B & $32-42$ & 14 & 11 & 17.46 & 9 & 20 & $3.55 \times 10^{-4}$ & $2.51 \times 10^{-5}$ & $5.39 \times 10^{-4}$ \\
\hline Azare 17 & 54 & KK \& B & $35-53$ & 18 & 8.73 & 8.73 & 20 & - & $1.72 \times 10^{-5}$ & $9.46 \times 10^{-7}$ & $1.22 \times 10^{-4}$ \\
\hline
\end{tabular}

$\mathrm{KK}=$ Kerri Kerri $\quad \mathrm{B}=$ Fractured Basement

Table 2 Transmissivity and hydraulic conductivity from step-drawdown and recovery tests

\begin{tabular}{|c|c|c|c|c|c|c|}
\hline \multirow{2}{*}{$\begin{array}{l}\text { Borehole } \\
\text { Number }\end{array}$} & \multicolumn{3}{|c|}{ Transmissivity $\left(\mathrm{m}^{2} / \mathrm{sec}\right)$} & \multicolumn{3}{|c|}{ Hydraulic conductivity $(\mathrm{m} / \mathrm{sec})$} \\
\hline & Step test & Recovery test & Average & Step test & Recovery test & Average \\
\hline 2 & No data & $2.15 \times 10^{-5}$ & $2.15 \times 10^{-5}$ & $2.15 \times 10^{-5}$ & $3.58 \times 10^{-6}$ & $3.58 \times 10^{-6}$ \\
\hline 4 & No data & $1.45 \times 10^{-5}$ & $1.45 \times 10^{-5}$ & $1.45 \times 10^{-5}$ & $1.62 \times 10^{-6}$ & $1.62 \times 10^{-6}$ \\
\hline 6 & No data & $7.30 \times 10^{-6}$ & $7.30 \times 10^{-6}$ & $7.30 \times 10^{-6}$ & $5.62 \times 10^{-7}$ & $5.62 \times 10^{-7}$ \\
\hline 7 & $1.24 \times 10^{-5}$ & $6.31 \times 10^{-5}$ & $3.78 \times 10^{-5}$ & $6.20 \times 10^{-7}$ & $3.16 \times 10^{-6}$ & $4.68 \times 10^{-6}$ \\
\hline 8 & $8.5 \times 10^{-5}$ & $1.50 \times 10^{-5}$ & $5.02 \times 10^{-5}$ & $6.09 \times 10^{-6}$ & $1.07 \times_{10^{-6}}$ & $3.58 \times 10^{-6}$ \\
\hline 9 & $8.30 \times 10^{-5}$ & $5.39 \times 10^{-5}$ & $6.85 \times 10^{-5}$ & $5.93 \times 10^{-6}$ & $3.85 \times 10^{-6}$ & $4.89 \times 10^{-6}$ \\
\hline 10 & $4.59 \times 10^{-5}$ & $1.89 \times 10^{-5}$ & $3.24 \times 10^{-5}$ & $3.83 \times 10^{-6}$ & $1.58 \times 10^{-6}$ & $2.71 \times 10^{-6}$ \\
\hline 11 & $25.86 \times 10^{-5}$ & $2.86 \times 10^{-5}$ & $2.86 \times 10^{-5}$ & $1.58 \times 10^{-6}$ & $1.59 \times 10^{-6}$ & $1.58 \times 10^{-6}$ \\
\hline 12 & $6.16 \times 10^{-6}$ & $2.79 \times 10^{-5}$ & $4.46 \times 10^{-5}$ & $3.2 \times 10^{-6}$ & $1.64 \times 10^{-6}$ & $2.63 \times 10^{-6}$ \\
\hline 14 & No data & $4.09 \times 10^{-5}$ & $4.09 \times 10^{-5}$ & No data & $2.05 \times 10^{-6}$ & $2.05 \times 10^{-6}$ \\
\hline 16 & $1.73 \times 10^{-4}$ & $3.55 \times 10^{-4}$ & $2.64 \times 10^{-4}$ & $1.24 \times 10^{-5}$ & $2.54 \times 10^{-5}$ & $1.89 \times 10^{-5}$ \\
\hline 17 & $5.34 \times 10^{-5}$ & $1.72 \times 10^{-5}$ & $3.35 \times 10^{-5}$ & $2.97 \times 10^{-6}$ & $9.56 \times 10^{-7}$ & $1.98 \times 10^{-6}$ \\
\hline
\end{tabular}


Conclusions: The hydraulic characteristics of aquifers within the Azare area are affected by the dominance of clay and clayey sand lithology. The presence of the fines has reduced the overall efficiency of the aquifers. The values of aquifer constants are generally low. Yield values show that even the most prolific borehole (BH16, $17.46 \mathrm{~m}^{3} / \mathrm{h}$ or $419.04 \mathrm{~m}^{3} /$ day) in the area is poor in terms of standard aquifer performance. More boreholes and water impoundment by earth dams are needed to increase the volume of water available for supply.

Acknowledgements: The authors are grateful to the Bauchi State Water Board, Nigeria, for making data available for this study. We are also indebted to the memory of the late Dr. E.H. Alabo of the Rivers State University of Science and Technology, Port Harcourt, who was very instrumental to the draft and completion of this work. The useful comments of Professor E.F.C. Dike of the Geology Programme, Abubakar Tafawa Balewa University, Bauchi, Nigeria, which improved the quality of the work are gratefully acknowledged.

\section{REFERENCES}

Adegoke, OS; Agumanu, AE; Benkhelil; MJ; Ajayi, P.O. (1986). New stratigraphic, sedimentologic and structural data on the Kerri Kerri Formation, Bauchi and Borno States, Nigeria. Jour. Afri. Earth Sci. Vol. 5, pp. 249-277.

Benkhelil, MJ (1989). The Origin and Evolution of the Cretaceous Benue Trough (Nigeria).Jour. Afri. Earth Sci. Vol. 8 pp.251-282.

Carter, J.D; Barber, W M.; Tait, E.A. (1963). The Geology of parts of Adamawa, Bauchi and Bornu provinces of North Eastern Nigeria. Geol. Surv. Nig. Bull. 30, 180p.

Cooper, HH; Jacob, CE. (1946). A generalized graphical method for evaluating formation constants and summarizing well-field history. Trans.Americ.geophysical Union 27. pp 526-534
Davis, SN; De Wiest, RJM (1966). Hydrogeology. John Wiley and Sons Inc. New York. 222 pp.

Dike, EFC (1990). Water supply to Misau Town, Bauchi State: structure, geology and aquifer types. Proc Nig. Assoc. Hydrogeologists 3rd National Conf. Zaranda Hotel Bauchi. Pp.100117.

Dike, EFC; Dan-Hassan, MA (1990). The Geology and Aquifer Properties of the Tertiary Kern-Kerr Formation, Bauchi State. Proc. Nig. Assoc. Hydrogeologists 3rd National Conf. Zaranda Hotel Bauchi. pp117-133

Driscoll, PFG (1986). Groundwater and wells. (2nd ed.) Johnson Division, 360p.

Du Preez, JW; Barber, DFM (1965). The distribution and chemical quality of groundwater in Northern Nigeria. Geol. Surv. Nig. Bull. 36, 93p.

Edok-Eter (1976). Geophysical Investigation for Groundwater, Bauchi State, Nigeria. Unpublished Reports Bauchi state Water Board. 246p.

Freeze, RA; Cherry, JA; (1979). Groundwater. Prentice Hall Inc. 304p.

Thompson, JH; (1958). The Geology and Hydrogeology of Gombe, Bauchi and Adamawa Provinces, Geol. Surv 